Article

\title{
The Difference of Knowledge and Behavior of College Students on Plastic Waste Problems
}

\author{
Rospita Odorlina P. Situmorang $1{ }^{1}$, Ta-Ching Liang ${ }^{2}$ and Shu-Chun Chang ${ }^{3, * \mathbb{C}}$ \\ 1 Department of Forestry, National Chung Hsing University, Taichung 402, Taiwan; pita_80s@yahoo.com \\ 2 Department of Leisure and Recreation, National Formosa University, Huwei Township, \\ Yunlin County 632, Taiwan; taching@nfu.edu.tw \\ 3 Graduate Institute of Bio-industry Management, National Chung Hsing University, Taichug 402, Taiwan \\ * Correspondence: kimichang@dragon.nchu.edu.tw; Tel.: +886-4228-40491 (ext. 21)
}

Received: 20 July 2020; Accepted: 21 September 2020; Published: 23 September 2020

\begin{abstract}
Environmental education in the academic level is the most effective way to increase environmental awareness of college students particularly in handling plastic waste problems. This study aimed to compare the student's knowledge and behavior on plastic waste problem between environmental science and social science students and to examine the correlation of knowledge and behavior to reduce plastic waste. Through survey of 98 students of National Chung Hsing University, Taichung, Taiwan, we compared the students' knowledge and behavior on plastic waste problems by $t$-Test and Chi-square analysis, and we used Kendall's rank correlation to evaluate the correlation of knowledge and behavior. This study found that the differences in majors resulted in the significant differences in knowledge on the negative impacts of plastic waste, where the students who are majoring in environmental sciences have higher score than the students in social science. Relating behaviors, the differences in majors also resulted in the significant different behaviors to reduce plastic usage, where the students with major in environmental sciences have the better behavior to reduce plastic usage for daily life than the social science students. These behaviors were shown in purchasing products with plastic packaging, preparing shopping bag, re-using plastic bags, taking own meal box, and having food on the sites to reduce single used plastic package. This study also found the positive correlation between environmental knowledge on plastic waste and behavior to reduce plastic waste in the daily life.
\end{abstract}

Keywords: environmental science; social science; knowledge; behavior; plastic waste reducing

\section{Introduction}

Most of the people around the world have been facilitated by plastic packaging. Based on the data provided by the Our World in Data, the global plastic production has increased from 2 million ton in 1950 to be 381 million ton in 2015, and the highest production (about 36\%) of plastic material is for packaging [1]. The increasing plastic usage in packaging has direct impact on the environment, especially to ocean because it is difficult to degrade plastic materials. Many efforts such as waste sorting and recycling plastic waste [2,3], banning and charging for plastic carrier bags [4,5], and using biodegradable plastic [6,7] have been applied to overcome the plastic waste problems. However, these efforts will not be optimal if people's awareness on plastic-based problems are still low.

Environmental Education (EE) has been applied in various educational levels to increase people's awareness toward the importance of environmental protection [8-10]. Environmental education is officially defined as the process of recognizing values and clarifying concepts necessary to understand and appreciate the interrelatedness among men, their culture and their biophysical surroundings [11,12]. Environmental education has objectives of developing knowledge and skills, positive attitudes, 
and commitment to protect and improve environment quality [13,14]. Environmental knowledge reflects the degree of understanding and recognizing environment issues that encourage an individual's responsibility for environmental protection $[13,15,16]$. Environmental knowledge encouragement is a basic prerequisite in forming the individual environmental responsible behavior $[17,18]$. The thinking process which involves self-evaluation [19], place attachment indicating the connection to the nature [20,21], and society [22] will affect the sensitivity to environmental problem. It later influences the environmental awareness and attitude. Attitude is the fundamental drivers of human behavior because it determines stimuli in which the individual will approach or avoid the environmental issues, while pro-environmental behavior or responsible behavior can be defined as the act of causing minimal damage to environment, or even beneficial to environment [23].

Related to the role of formal education to form pro-environmental behavior, previous studies mentioned that majors at university level are the affecting factors influencing the sustainable behavior of students [24-26]. Majors that mainly group as science and non-science (social science) are the indicator how the schools arrange the curriculum or courses, and the science-based majors are having more courses that related to environmental studies. Chuvieco et al. [24] and Talai et al. [27] found that students who have majors in environmental studies had better attitude toward environmental protection compared to the students who had no connection with environmental science. However, the different result from Hasan et al. [28] study found that science and social science majors did not show a significant different on environmental behavior. Social connection, past experience, even socio-economic conditions are factors that also influence environmental behavior [17,29]. Until now, there is still a debate that whether the majors related to environmental sciences are effective or not to increase the students' attitude to protect environment. The studies that discuss the sustainable behavior on plastic waste problem specifically also are still limited. Plastic waste issues are important to be examined because plastic waste problem is an environmental problem experienced by most of the countries due to the rapid increase of plastic waste. Therefore, this study has purposes to compare the knowledge on the negative impact of plastic waste of the students who have major in environmental sciences and social science; to compare behaviors to reduce plastic usage of the students who have major in environmental and social science; and to examine the correlation of environmental knowledge on plastic waste issues and behavior to reduce plastic uses.

\section{Literature Review and Hypothesis Development}

To understand the individual environmental behavior, Hungerford and Volk [30] figured out the behavior change model which mentioned that when knowledge increases, environmentally favorable attitudes that lead toward taking responsible environmental actions are developed. Earlier in 1985, Ajzen and Fishen assumed that human behavior is grounded in rational thoughts as subjective norm and beliefs. The rational thought and believe to environmental issues will lead to the attitude and intention of action to protect environment. Later, Glenda Hanna in 1995 combined both theories and assumed that the preceding factors such as demographic factor and past experience related to nature influence the environmental behavior as describe in [29]. The model is developed in Figure 1.

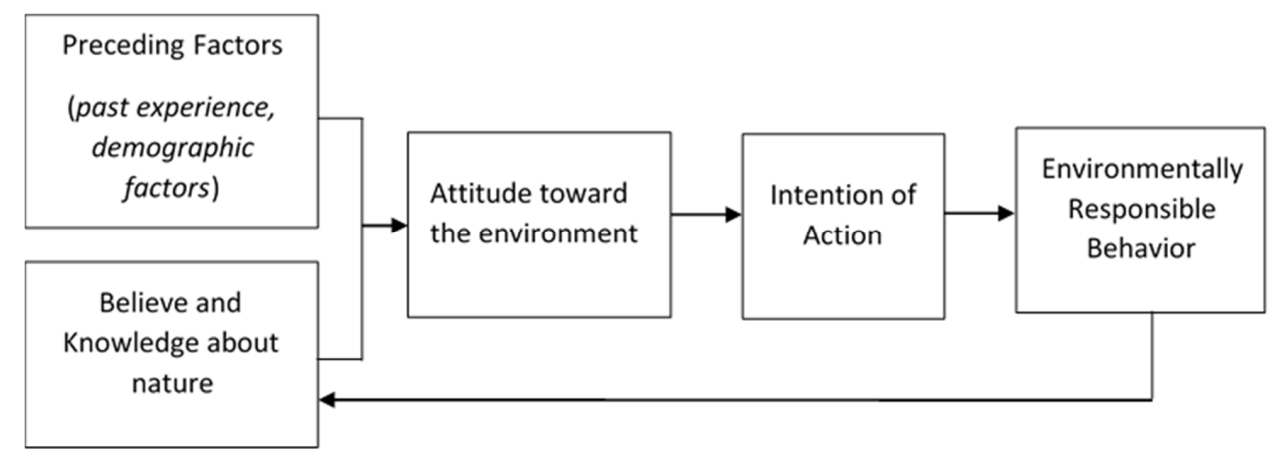

Figure 1. The concept on environmental behavior change. 
Referring the concepts and theories on the environmental behavior change, it can be interpreted that the knowledge and preceding factors affect the students' attitude, action and behavior to protect the environment. Braun and Dierkes [31] mentioned that people who more involve in environmental education, the intention to counter the environmental issues will increase. Environmental education can be inducted in-class activities, experiments, and fieldtrip which enable students to understand basic theories and methods to solve environmental problems through prose thinking. Therefore, Faize and Akhtar [25] stated that the student should get more exposure to natural environment by visiting natural areas and neighborhood for seeking environmental problems as it provides better knowledge on environmental issues particularly to identify problem and to infer solution. Regarding behavior, Chuvieco et al. [24] and Talay, et al. [27] found that the students at the science has the better attitude and behavior towards environmental problems. By focusing on pro-environmental behavior to reduce plastic waste as an important action expected by countries, the hypotheses built in this study are:

Hypothesis 1 (H1). There is a significant difference of different majors on knowledge on plastic waste issues. The students having majors related to environmental sciences have the higher understanding on negative impact of plastic packaging than students in social sciences.

Hypothesis 2 (H2). There is a significant difference of different majors on behavior to reduce plastic waste. The students having major related to environmental are more likely to reduce the use of plastic packaging in their daily lives than students who have majors in social sciences.

Hypothesis 3 (H3). There is a positive correlation between knowledge on negative impact of plastic waste and the students' behavior to reduce plastic consumption.

\section{Method}

\subsection{Participant, Sampling Technique, and Procedure}

Data collection were carried out through survey method by providing questionnaires. We conducted survey to 98 students of National Chung Hsing (NCHU), Taichung City, Taiwan. The survey was conducted by face-to-face interview at several spots at NCHU campus. The samples were determined randomly by first asking their willingness to fill in the questionnaire form. The collected samples were divided into two groups i.e., majors related to environmental sciences and majors not related to environmental sciences or related to social sciences. To validate the group of majors, we searched the NCHU website and determined the group of majors as follows: (1) majors related to environmental sciences are majors or departments belong to College of Agricultural and Natural resources, Department of Environmental engineering, College of Science, and College of Life Science; and (2) social science majors consist of majors in the College of Liberal Art, College of Engineering, College of Law and Politic, and College of Management.

\subsection{Questionnaire Setting}

The questionnaire was divided into four parts including socio-economic backgrounds, experience on environmental education both when studying at NCHU or other previous schools, environmental knowledge on plastic waste issues, and behavior toward plastic waste. The questions related to environmental education experience were whether the students take/took or have/had course/s (in class) related to environmental studies and whether the students take/took or have/had field trip/s that related to environmental studies organized by campus. The question related to knowledge on plastic waste issues is presented in Table 1. Eight questions regarding the negative impacts of plastic waste to environment and human health were modified from Derraik [32] and Thompson et al. [33] studies. 
Table 1. List of questions regarding plastic waste issues.

\begin{tabular}{lrl}
\hline & Some Problems Caused by Plastic & Answer \\
\hline Q1 & Plastic is a substantial part of domestic wastes in landfill & Yes/No \\
Q2 & Plastic is undegradable waste & Yes/No \\
Q3 & Plastic waste enters body of river & Yes/No \\
Q4 & Marine species can ingest plastic debris & Yes/No \\
Q5 & Marine species can become entangled in plastic debris & Yes/No \\
Q6 & Plastic debris can lead to severe injury and death marine species & Yes/No \\
Q7 & Plastic package contains monomers and additive chemicals & Yes/No \\
Q8 & Accumulation of plastic monomers in the human body is potential to cause diseases & Yes/No \\
Q9 & Yes/No \\
\hline
\end{tabular}

The assessment of the behavioral differences developed from several studies $[24,34,35]$ consists of six questions concerning daily habits on plastic packaging usage and actions taken to reduce plastic packaging. The questions include: (Q1) How many times did you buy product packaged by plastic in the last week? (Q2) Do you mostly prepare your own shopping bag when shopping? (Q3) Do you reuse plastic bag/containers in most of your life? (Q4) When buying food form outside (in campus or around campus), do you take your own meal box?; (Q5) When buying drink from outside, do you take your own cup holder to carry the drinks/soft drinks?; (Q6) When taking meal, do you prefer taking food in the spots (restaurants/food stalls) rather than taking home/outside? The prepared answers for all the questions was yes, no, and others.

\subsection{Analysis}

To evaluate the significance of the different majors on environmental education experience, we used Chi Square test and crosstab to understand the differences by calculating the frequency of each answer option. For the difference of environmental knowledge, we used independent $T$-test to compare the mean score of the two groups. The binary answer options were transformed to quantitative data (Yes $=1, \mathrm{No}_{2} 0$ ) to get the final score of each respondent, and the maximum total score was 9, and the lowest was 0. Furthermore, we used Chi Square analysis to find out whether there is a statistically significant difference behavior to reduce plastic waste of the two groups of majors. Lastly, the correlation of knowledge and behavior toward plastic was examined by using Kendall rank correlation. The answer of option of the six questions related to behavior was ranked to get the ordinal data. Example, for Q1: How many times did you buy products packaged by plastic in the last week? (Everyday $=1,5-6$ days $=2,3-4$ days $=3,1-2$ days $=4$, and None $=6$ ), or Q2: Do you mostly prepare your own shopping bag when shopping? (Yes $=3$, Others (sometimes, ect.) $=2$, and No $=1$ ).

\section{Results}

\subsection{Characteristics of the Respondents}

Characteristic of the respondents is provided in Table 2.

\subsection{Environmental Education}

Levene's test on homogeneity variance of the two groups of majors was carried out to evaluate the significance of the two groups on courses relating environmental studies. The probability value is 0.339 which is greater than 0.05 (significant). The $p$ value greater than 0.05 means that each group is homogenous. Hence, the following analysis on the different of group of majors toward environmental education gained during the study at NCHU were carried out in this study, as it is presented in Table 3. 
Table 2. Characteristic of the Respondents.

\begin{tabular}{cccc}
\hline No & Description & Number of Samples & Percentage (\%) \\
\hline 1. & Gender & & \\
a. Male & 60 & 61.22 \\
b. Female & Age & 38 & 38.78 \\
& a. $\leq 20$ years old & 49 & 50.00 \\
b. $21-25$ years old & 36 & 36.73 \\
c. $26-30$ years old & 8 & 8.16 \\
d. $>31$ years old & 5 & 5.10 \\
3. Current level of education & & \\
& a. Undergraduate & 70 & 71.43 \\
b. Master & 21 & 21.43 \\
c. Doctoral/PhD & 7 & 7.14 \\
4. Nationality & & 71.43 \\
& a. Local Students (Taiwanese) & 70 & 28.57 \\
\hline
\end{tabular}

Table 3. Difference of group majors and environmental education experience.

\begin{tabular}{|c|c|c|c|c|c|c|}
\hline \multirow[b]{2}{*}{ Statements } & \multicolumn{3}{|c|}{ Group Majors $(N=98)$} & \multirow[b]{2}{*}{$x^{2}$} & \multirow[b]{2}{*}{ df } & \multirow[b]{2}{*}{$p$-Value } \\
\hline & $\begin{array}{c}\text { Environmental Sciences } \\
n(\%) \\
(n=52)\end{array}$ & $\begin{array}{l}\text { Social Sciences } \\
\qquad \begin{array}{c}n(\%) \\
(n=46)\end{array}\end{array}$ & $\begin{array}{l}\text { Total } \\
n(\%)\end{array}$ & & & \\
\hline \multicolumn{7}{|c|}{ Taking environmental course/s (in-class) } \\
\hline Yes & $38(73.08)$ & $14(30.43)$ & $52(53.06)$ & 18.20 & 2 & $0.00012 *$ \\
\hline No & $14(26.92)$ & $31(67.39)$ & $45(45.92)$ & & & \\
\hline Others & $0(0.00)$ & $1(2.00)$ & $1(1.02)$ & & & \\
\hline \multicolumn{7}{|c|}{ Having fieldtrip activities (out-class) } \\
\hline Yes & $26(50.00)$ & $7(15.22)$ & $52(53.06)$ & 13.22 & 1 & $0.00028 *$ \\
\hline No & $26(50.00)$ & $39(84.78)$ & $46(46.94)$ & & & \\
\hline
\end{tabular}

The significant results shown in Table 3 denotes that the two group majors have the different experience on environmental education both in-class and out-class activities. The higher percentage of students who take courses related to environmental education belongs to students having majors related to environmental sciences (78.79\% for in-class courses and $50.50 \%$ for out-class or fieldtrip), respectively. Even though percentage of environmental science majors is higher on environmental bases-courses taking, $26.92 \%$ of the students have not taken the courses during their study. Or vice versa, $30.34 \%$ students in social science taking courses related environmental studies. It can be explained that the group major related to environmental sciences in this study includes many specific majors which also cover science majors such as agricultural and basic sciences which the environmental-based courses are not compulsory courses for them (or election courses). It is also possible that they have not taken the courses when this study was carried out. Likewise, the students at social science majors have opportunity to take courses related environmental studies because in the course selection system in $\mathrm{NCHU}$, the university allows students to select elective courses from other departments if they have interested to take courses related environmental issues. It also can happen because social science-based majors such as economics and law also provide lessons related environment issues, as it is mentioned in previous research [36]. However, in general, number of students who are majoring in environmental sciences have more environmental education through the various courses provided in curriculum. 


\subsection{Correlation between Majors and Students' Knowledge on Negative Impact of Plastic Packaging}

The difference mean score on the negative impact of plastic waste of the two groups of majors is provided in Table 4 . This result shows that different major significantly correlates with students' knowledge, where the mean score of the students who have majors related to environmental science is higher than students in social science (Hypothesis 1 accepted). This result proves that the student who have more engaged to environmental studies have higher knowledge on the negative impact of plastic waste problems.

Table 4. $T$-Test analysis on correlation of majors and students' knowledge level toward negative impact of plastic waste.

\begin{tabular}{cccccc}
\hline Major Groups & $\boldsymbol{n}$ & Mean & SD & $\boldsymbol{t}$ & $\boldsymbol{p}$-Value \\
\hline Environmental sciences & 52 & 8.7308 & 0.6298 & 4.092 & $0.00008 *$ \\
Social sciences & 46 & 7.9333 & 1.2321 & & \\
\hline
\end{tabular}

Note. ${ }^{*}$ The mean difference is significant at 0.05 .

\subsection{Correlation between Majors and Students Behavior to Reduce Plastic Bag Usage}

The last stage of environmental education is positive actions to protect the environment. This is a manifestation of environmental knowledge, attitude, and commitment to reduce plastic waste. The behavior of students toward plastic packaging is presented in Table 5 .

Table 5. Difference of majors and behavior to reduce plastic bag usage.

\begin{tabular}{|c|c|c|c|c|c|c|}
\hline \multirow[b]{2}{*}{ Statements } & \multicolumn{3}{|c|}{ Group Majors $(N=98)$} & \multirow[b]{2}{*}{$x^{2}$} & \multirow[b]{2}{*}{ df } & \multirow[b]{2}{*}{$p$-Value } \\
\hline & $\begin{array}{c}\text { Environmental Sciences } \\
n(\%)\end{array}$ & $\begin{array}{c}\text { Social Sciences } \\
n(\%)\end{array}$ & Total & & & \\
\hline \multicolumn{7}{|c|}{ 1. Buying products packaged by plastics } \\
\hline Every day & $9(17.31)$ & $29(63.04)$ & $38(38.78)$ & 25.096 & 4 & 0.00048 * \\
\hline 5-6 days & $9(17.31)$ & $8(17.39)$ & $17(17.35)$ & & & \\
\hline $3-4$ days & $15(28.85)$ & $5(10.87)$ & $20(20.41)$ & & & \\
\hline $1-2$ days & $14(26.92)$ & $3(6.52)$ & $17(17.35)$ & & & \\
\hline None & $5(9.62)$ & $1(2.17)$ & $6(6.12)$ & & & \\
\hline \multicolumn{7}{|c|}{ 2. Preparing own shopping bag } \\
\hline Yes & $39(75.00)$ & $27(58.70)$ & $66(67.34)$ & 6.639 & 2 & 0.036 * \\
\hline No & $9(17.31)$ & $18(39.13)$ & $27(27.55)$ & & & \\
\hline Others & $4(7.69)$ & $1(2.17)$ & $5(5.10)$ & & & \\
\hline \multicolumn{7}{|c|}{ 3. Reusing plastic bags } \\
\hline Yes & $39(75.00)$ & $17(36.96)$ & $56(57.14)$ & 15.069 & 2 & $0.001 *$ \\
\hline No & $11(21.15)$ & $27(58.70)$ & $38(38.78)$ & & & \\
\hline Others & $2(2.85)$ & $2(4.34)$ & $4(4.08)$ & & & \\
\hline \multicolumn{7}{|c|}{ 4. Taking own meal box when buying food } \\
\hline Yes & $13(25.00)$ & $2(4.35)$ & $15(15.30)$ & 8.392 & 2 & $0.015^{*}$ \\
\hline No & $36(69.23)$ & $42(91.30)$ & $78(79.59)$ & & & \\
\hline Others & $3(5.77)$ & $2(4.35)$ & $5(5.10)$ & & & \\
\hline \multicolumn{7}{|c|}{ 5. Taking own cup holder when buying drinks/soft drinks } \\
\hline Yes & $11(21.15)$ & $4(8.70)$ & $15(15.30)$ & 4.131 & 2 & 0.127 \\
\hline No & 35 (67.31) & $39(84.78)$ & 74 (75.51) & & & \\
\hline Others & $6(11.54)$ & $3(6.52)$ & $9(9.18)$ & & & \\
\hline \multicolumn{7}{|c|}{$\begin{array}{l}\text { 6. Having food in restaurant/food stalls rather than taking home to reduce single used plastic } \\
\text { packaging/trash }\end{array}$} \\
\hline Yes & 47 (90.38) & $40(86.95)$ & 87 (88.78) & 5.502 & 2 & $0.044^{*}$ \\
\hline No & $0(0.00)$ & $4(8.70)$ & $4(4.08)$ & & & \\
\hline Others & $5(9.62)$ & $2(4.35)$ & 7 (7.14) & & & \\
\hline
\end{tabular}


Table 5 shows the significant difference of the different majors on behavior to reduce plastic bags in their daily life indicated by six sustainable behaviors to reduce plastic bag consumption. From the six evaluated behaviors, five of them are significant, and it can be said that different group of majors showed different behavior on plastic bag usage, and the students enrolled in environmental sciences have better behavior to reduce plastic containers (Hypothesis 2 accepted). It can be seen from the percentage of the students who have never bought plastic packaging (Q1) in the past last week is higher for the students in the group of environmental science majors (9.62\% compare to $2.17 \%)$. Relating shopping habits, the percentage of students who carrying their own bag when shopping (Q2) is higher for the group of the students enrolled in the environmental science majors $(75.00 \%$ compared to $58.70 \%$ ), and sustainable behavior to reuse plastic bag (Q3) is higher for the students in environmental science majors $(75.00 \%$ compared to $36.96 \%$ ). Relating eating behavior to reduce plastic containers to carry foods, the percentage of student who prepare their own meal box when buying food meals is higher for the group of students who are majored in the environment science $(25.00 \%$ compared to $4.35 \%$ ). Likewise, percentage of the students who prefer to take food at the sites rather than taking home (usually taken to the class/office/laboratories) is higher for the students enrolled in the environment-based majors (90.38\% compared to $86.95 \%)$, respectively.

\subsection{Correlation between Knowledge and Behavior}

Correlation of knowledge toward sustainable behavior of the students to reduce plastic consumption is presented in Table 6. The result shows the significant correlation between the student's knowledge toward their behavior to reduce plastic usage in their daily life. Correlation coefficient is positive (0.361) which mean that increasing knowledge on plastic waste problem will increase the student behavior to reduce plastic usage (Hypothesis 3 accepted). Specifically, the students' knowledge on plastic waste is positively correlate with behavior to reduce to buy product packaged by plastic (Q1), reused plastic bags (Q3), taking meal box when buying food (Q4), and not taking food at home to reduce the single used plastic packaging (Q6). For the Q2 and Q5, coefficient correlation is positive, but the correlation strength is very weak and not significant.

Table 6. Kendall's rank correlation between knowledge on negative impact of plastic waste and students' behavior to reduce plastic packaging $(N=98)$.

\begin{tabular}{clc}
\hline Variables & Measurement & Knowledge \\
\hline Behaviors (overall) & Correlation coef. & $0.361^{* *}$ \\
Q1. Reducing to buy products packaged by plastics & Correlation coef. & $0.277^{* *}$ \\
Q2. Preparing own shopping bag & Correlation coef. & 0.145 \\
Q3. Reusing plastic bags & Correlation coef. & $0.485^{* *}$ \\
Q4. Taking own meal box & Correlation coef. & $0.213^{*}$ \\
Q5. Taking own cup holder & Correlation coef. & 0.073 \\
Q6. Having food in restaurant/food stalls & Correlation coef. & $0.219^{*}$ \\
\hline
\end{tabular}

Note: ${ }^{* *}$ Correlation is significant at the 0.01 level. ${ }^{*}$ Correlation is significant at the 0.05 level.

\section{Discussion}

Environmental education has objective to develop knowledge, skills, positive attitudes, and commitment to protect and improve environment quality $[13,14]$, which in this study, it was evaluated by knowledge on negative impact of plastic waste to environment and human life and behavior to reduce plastic usage. The students who have major in environmental science majors have the better knowledge to recognize plastic waste issues and the better behavior to protect environment by reducing plastic usage daily because they have more attached to environmental education that can be gained in the courses and field experiences, as the difference is described in Table 3.

The difference of environmental education of students indicated by different majors have made the different cognition on plastic issues. The students who have majors in environmental sciences 
in NCHU have a better ability to analyze issues regarding plastic waste indicated by their higher score compared to the social sciences as presented in Table 4. This study proves that people who more involve in environmental education, have the better ability to analyze environmental issues, as it previous mentioned by Braun and Dierkes [31]. The plastic waste problem is an environmental issue that has been known by most of the people. However, the specific understanding such as the impacts on marine life and health is more understood by those who get the more environmental education. Van et al. [37] also stated that some of the general issues of plastic pollution (plastic pollutes rivers, roads, and oceans) can be traced by most of the respondents, but the specific issues such as plastic harming to marine life (killing turtle and any other marine species) and the effect of plastic monomers to environment and human body [25] could answered by few respondents that mostly majored at environmental sciences. Environmental courses have improved literacy and cognition to environmental issues of the environmental science students [38,39]. Faize and Akhtar [25] also said that the students in the environmental study program are more connected to nature, and they are more sensitive to understand the environmental problem which enable them to deliver their knowledge than those who less get environmental education. Elmassah et al. [40] also confirmed that different colleges or departments in universities significantly influence the content of curriculum and student's activities that later influence their competency and knowledge on environmental issues. This finding also in line with the previous studies that revealed that the environmental knowledge of students majored in environmental science is higher than the environmental knowledge of students majored in social science $[27,41]$.

The difference of students' majors also showed the significant different behavior to reduce plastic packaging consumption which is represented by their willingness to reduce to buy items with plastic packaging, to take their own bag when shopping, to re-use plastic containers, to take meal box and cup holder, and taking food in the eating spots. Single-use plastic bag is the major cause of plastic waste increase [5,37]. Ritchie [1] also said that plastic packaging is the main contributor of plastic waste causing environmental problem. Its nature that is difficult to be degraded creates garbage piles in the landfills and disturbs the marine life when the plastics enter the body rivers and end up in the oceans [32]. Meanwhile, people still use plastic intensively because it is convenience to be used, cheap, and the plastic banning regulations are still not strict in most of countries. Hence, the role of environmental education is important to increase the people behavior to consciously reduce the use of plastic and make it as a lifestyle such as when doing shopping, buying foods or drink. Interestingly, the students who get more environmental education, that is the students in environmental science majors, have the better behavior to reduce single-use plastic items when buying their stuffs. It indicates that the environmental education effectively influences the sustainable behavior of students.

To explain this, Estrada-Vidal and Tójar-Hurtado [42] argued that environmental education teaches people to adopt habits that improve the quality environment, to act on their environmental thinking, and to know how to act and to solve environmental problems started from themselves and spread it to others. Hence, exposure of environmental education in the core curriculum influence the students' cognition and belief, and improve their awareness on environmental issues [43] that make students in environmental science majors are more aware than the social science students. It is also confirmed in Chuvieco et al. [24] and Heyl, Moyano Díaz, and Cifuentes [44] studies. Their studies revealed that students who have majors in environmental science have more attention and behavior to protect environment, as an example to re-use plastic bottles and other reusable packaging to reduce plastic bag usage. In different issues, such as behavior on using energy and waste management [41], waste separation [27], and recycling paper [45], it was also found that the science students are more inclined toward resource conservation and environmental protection behavior than the social science students. Arnocky and Stroink [46] and Nkoana [38] added that environmental education courses and out-door experiences have increased the levels of environmental concern of the students enrolled in environmental base majors. 
The result of the study also supports the theory behavioral change which mentioned when knowledge increases, environmentally favorable attitudes that lead toward taking responsible environmental actions are developed [23]. It is shown by the positive correlation of knowledge and sustainable behavior to reduce plastic use. The students who have higher knowledge have the higher positive behavior toward plastic waste reduction. Steg and Vlek [23] mentioned some factors that affect the behavior change, and one of them is cognitive process that can be gained through environmental education. The process of cognition that repeats continuously will change attitudes that eventually become habits [38]. As an example, taking own bags when shopping is initially considered as weighing cost [23], but over the time, it became a habit because the price of plastic bags is very cheap (in Taiwan, one plastic bag is priced NT \$1-2 or around US\$ $0.034-0.068$ ). Therefore, people who choose to carry bags or to re-use plastic bags are due to the environmental awareness. It also applies to the habit in bringing own meal box when ordering food. The past researchers also revealed the correlation of environmental knowledge and behavior which mentioned that the environmental knowledge positively affect the environmental behavior $[13,16,23,47]$.

\section{Conclusions}

The difference of majors in the environmental field affect the students' knowledge and attitude toward the plastic waste problems recognition. The students with environmental based major have higher understanding on negative impacts of plastic waste than the student enrolled in social-science majors. Majors relating environmental studies have also proved to develop the better pro-environmental behavior which is shown by the higher percentage of the students from the environmental based majors to reduce plastic packed products, prepare the shopping bag, re-using plastic bags, take own meal box, and having food on the sites. The reason is that students in the environmental based majors are more engaged in environmental education that they can gain in courses, fieldtrips, experiments, and other activities which lead to form their sustainable behavior. By comparing the different behaviors of students in environmental based major and social science majors, this study explains that higher intensity of environmental education in university level is effectively influence he student's awareness on plastic waste problem. The higher environmental education gained by the students who enrolled in environmental based majors the more increase their environmental knowledge and behavior toward plastic waste reduction. Hence, the environmental education at academic level is still proper to be implemented to increase people awareness on environmental issues.

Author Contributions: Conceptualization, methodology, data collection, analysis, validation, and written by S.-C.C., R.O.P.S. and T.-C.L.; Supervision by S.-C.C. All authors have read and agreed to the published version of the manuscript.

Funding: This research received no external funding.

Conflicts of Interest: The authors declare no conflict of interest.

\section{References}

1. Ritchie, H. Our World in Data, Plastic Pollution. 2018. Available online: https://ourworldindata.org/plasticpollution (accessed on 2 July 2020).

2. Awoyera, P.O.; Adesina, A. Plastic wastes to construction products: Status, limitations and future perspective. Case Stud. Constr. Mater. 2020, 12, e00330. [CrossRef]

3. Jang, Y.C.; Lee, G.; Kwon, Y.; Lim, J.H.; Jeong, J.H. Recycling and management practices of plastic packaging waste towards a circular economy in South Korea. Res. Conserv. Recycl. 2020, 158, 104798. [CrossRef]

4. Nielsen, T.D.; Holmberg, K.; Stripple, J. Need a bag? A review of public policies on plastic carrier bags-Where, how and to what effect? Waste Manag. 2019, 87, 428-440. [CrossRef]

5. Wagner, T.P. Reducing single-use plastic shopping bags in the USA. Waste Manag. 2017, 70, 3-12. [CrossRef] [PubMed] 
6. Dilkes-Hoffman, L.S.; Pratt, S.; Lant, P.A.; Laycock, B. The role of biodegradable plastic in solving plastic solid waste accumulation. In Plastics to Energy; School of Chemical Engineering, The University of Queensland: St Lucia, QLD, Australia, 2019; pp. 469-505.

7. Shen, M.; Song, B.; Zeng, G.; Zhang, Y.; Huang, W.; Wen, X.; Tang, W. Are biodegradable plastics a promising solution to solve the global plastic pollution? Environ. Pollut. 2020, 263, 114469. [CrossRef] [PubMed]

8. Kodama, T. Environmental Education in Formal Education in Japan. Jpn. J. Environ. Educ. 2017, 26, 21-26. [CrossRef]

9. Paredes-Chi, A.A.; Viga-de Alva, M.D. Environmental education (EE) policy and content of the contemporary (2009-2017) Mexican national curriculum for primary schools. Environ. Educ. Res. 2017, 24, 564-580. [CrossRef]

10. Ramadhan, S.; Sukma, E.; Indriyani, V. Environmental education and disaster mitigation through language. IOP Conf. Ser. Earth Environ. Sci. 2019, 314, 012054. [CrossRef]

11. Khademi-Vidra, A. Curriculum Planning of the Environmental Education. J. Cent. Eur. Green Innov. 2017, 5, 65-80.

12. Pérez, A.V.; Gámez, M.R.; Briones, V.F.V.; Viteri, C.G.V.; Molina, L.A.V. Sustainable development seen from environmental training in university linkage. Int. J. Life Sci. 2018, 2, 12-20. [CrossRef]

13. Maurer, M.; Bogner, F.X. Modelling Environmental Literacy with environmental knowledge, values and (reported) behaviour. Stud. Educ. Eval. 2020, 65, 100863. [CrossRef]

14. Pulkki, J.; Dahlin, B.; Värri, V.M. Environmental education as a lived-body practice? A contemplative pedagogy perspective. J. Philos. Educ. 2017, 51, 214-229. [CrossRef]

15. Clayton, S.; Bexell, S.M.; Xu, P.; Tang, Y.F.; Li, W.J.; Chen, L. Environmental literacy and nature experience in Chengdu, China. Environ. Educ. Res. 2019, 25, 1105-1118. [CrossRef]

16. Otto, S.; Pensini, P. Nature-based environmental education of children: Environmental knowledge and connectedness to nature, together, are related to ecological behaviour. Glob. Environ. Chang. 2017, 47, 88-94. [CrossRef]

17. Levy, A.; Orion, N.; Leshem, Y. Variables that influence the environmental behavior of adults. Environ. Educ. Res. 2016, 24, 307-325. [CrossRef]

18. Liu, P.; Teng, M.; Han, C. How does environmental knowledge translate into pro-environmental behaviors? The mediating role of environmental attitudes and behavioral intentions. Sci. Total Environ. 2020, 728, 138126. [CrossRef] [PubMed]

19. Pace, P. Self-evaluation as a tool in developing environmental responsibility. J. Teach. Educ. Sustain. 2010, 12, 5-26. [CrossRef]

20. Cheng, T.M.; Wu, H.C. How do environmental knowledge, environmental sensitivity, and place attachment affect environmentally responsible behavior? An integrated approach for sustainable island tourism. J. Sustain. Tour. 2015, 23, 557-576. [CrossRef]

21. Čulin, J.; Bielić, T.; Jakšić, K. Suggestions for improving the effectiveness of environmental education in the maritime sector. Pomorstvo 2019, 33, 232-237. [CrossRef]

22. Severo, E.A.; Guimarães, J.C.F.D.; Dellarmelin, M.L.; Ribeiro, R.P. The Influence of Social Networks on Environmental Awareness and the Social Responsibility of Generations. BBR Braz. Bus. Rev. 2019, 16, 500-518. [CrossRef]

23. Steg, L.; Vlek, C. Encouraging pro-environmental behaviour: An integrative review and research agenda. J. Environ. Psychol. 2009, 29, 309-317. [CrossRef]

24. Chuvieco, E.; Burgui-Burgui, M.; Da Silva, E.V.; Hussein, K.; Alkaabi, K. Factors affecting environmental sustainability habits of university students: Intercomparison analysis in three countries (Spain, Brazil and UAE). J. Clean. Prod. 2018, 198, 1372-1380. [CrossRef]

25. Faize, F.A.; Akhtar, M. Addressing environmental knowledge and environmental attitude in undergraduate students through scientific argumentation. J. Clean. Prod. 2019, 252, 119928. [CrossRef]

26. Freije, A.M.; Hussain, T.; Salman, E.A. Global warming awareness among the University of Bahrain science students. J. Assoc. Arab Univ. Basic Appl. Sci. 2017, 22, 9-16. [CrossRef]

27. Talay, I.; Gunduz, S.; Akpinar, N. On the status of environmental education and awareness of undergraduate students at Ankara University, Turkey. Int. J. Environ. Pollut. 2004, 21, 293-308. [CrossRef] 
28. Hasan, S.N.M.S.; Harun, R.; Hock, L.K. Application of theory of planned behavior in measuring the behavior to reduce plastic consumption among students at Universiti Putra Malaysia, Malaysia. Procedia Environ. Sci. 2015, 30, 195-200. [CrossRef]

29. Akintunde, E.A. Theories and concepts for human behavior in environmental preservation. J. Environ. Sci. Public Health 2017, 1, 120-132. [CrossRef]

30. Hungerford, H.R.; Volk, T.L. Changing learner behavior through environmental education. J. Environ. Edu. 1990, 21, 8-21. [CrossRef]

31. Braun, T.; Dierkes, P. Connecting students to nature-how intensity of nature experience and student age influence the success of outdoor education programs. Environ. Educ. Res. 2016, 23, 937-949. [CrossRef]

32. Derraik, J.G. The pollution of the marine environment by plastic debris: A review. Mar. Pollut. Bull. 2002, 44, 842-852. [CrossRef]

33. Thompson, R.C.; Moore, C.J.; Vom Saal, F.S.; Swan, S.H. Plastics, the environment and human health: Current consensus and future trends. Philos. Trans. R. Soc. Biol. Sci. 2009, 364, 2153-2166. [CrossRef] [PubMed]

34. Gallego-Schmid, A.; Mendoza, J.M.F.; Azapagic, A. Improving the environmental sustainability of reusable food containers in Europe. Sci. Total Environ. 2018, 628, 979-989. [CrossRef] [PubMed]

35. Khan, F.; Ahmed, W.; Najmi, A. Understanding consumers' behavior intentions towards dealing with the plastic waste: Perspective of a developing country. Res. Conserv. Recycl. 2019, 142, 49-58. [CrossRef]

36. Wieland, J.R.; Fitzgibbons, D.E. Integrating corporate sustainability and organizational strategy within the undergraduate business curriculum. Organ. Manag. J. 2013, 10, 255-266. [CrossRef]

37. Van Rensburg, M.L.; S'phumelele, L.N.; Dube, T. The 'plastic waste era'; social perceptions towards single-use plastic consumption and impacts on the marine environment in Durban, South Africa. Appl. Geogr. 2020, 114, 102132. [CrossRef]

38. Nkoana, E.M. Exploring the effects of an environmental education course on the awareness and perceptions of climate change risks among seventh and eighth grade learners in South Africa. Int. Res. Geogr. Environ. Educ. 2020, 29, 7-22. [CrossRef]

39. Umuhire, M.L.; Fang, Q. Method and application of ocean environmental awareness measurement: Lessons learnt from university students of China. Mar. Pollut. Bull. 2016, 102, 289-294. [CrossRef]

40. Elmassah, S.; Biltagy, M.; Gamal, D. Engendering sustainable development competencies in higher education: The case of Egypt. J. Clean. Prod. 2020, 121959. [CrossRef]

41. Wang, R.; Qi, R.; Cheng, J.; Zhu, Y.; Lu, P. The behavior and cognition of ecological civilization among Chinese university students. J. Clean. Prod. 2020, 243, 118464. [CrossRef]

42. Estrada-Vidal, L.I.; Tójar-Hurtado, J.C. College student knowledge and attitudes related to Sustainability Education and environmental health. Procedia-Soc. Behav. Sci. 2017, 237, 386-392. [CrossRef]

43. Hess, D.J.; Maki, A. Climate change belief, sustainability education, and political values: Assessing the need for higher-education curriculum reform. J. Clean. Prod. 2019, 228, 1157-1166. [CrossRef]

44. Heyl, M.; Moyano Díaz, E.; Cifuentes, L. Environmental attitudes and behaviors of college students: A case study conducted at a chilean university. Rev. Latinoam. Psicol. 2013, 45, 487-500. [CrossRef]

45. Meyer, A. Heterogeneity in the preferences and pro-environmental behavior of college students: The effects of years on campus, demographics, and external factors. J. Clean. Prod. 2016, 112, 3451-3463. [CrossRef]

46. Arnocky, S.; Stroink, M.L. Variation in environmentalism among university students: Majoring in outdoor recreation, parks, and tourism predicts environmental concerns and behaviors. J. Environ. Educ. 2011, 42, 137-151. [CrossRef]

47. Salahodjaev, R. Is there a link between cognitive abilities and environmental awareness? Cross-national evidence. Environ. Res. 2018, 166, 86-90. [CrossRef]

(C) 2020 by the authors. Licensee MDPI, Basel, Switzerland. This article is an open access article distributed under the terms and conditions of the Creative Commons Attribution (CC BY) license (http://creativecommons.org/licenses/by/4.0/). 